ground surrounding it. Henry Youle Hind, one of the first geologists to visit the Saskatchewan prairies, showed the geographic position of the Aiktow Erratic on a map and described the boulder as follows in his report (1859. Northwest Territory. Reports of progress together with a preliminary and general report of the Assiniboine and Saskatchewan exploring expedition. Toronto, John Lovell, p. 57):

"About fourteen miles from the [South] Saskatchewan [River] there is a gigantic erratic of unfossiferous [sic!] rock on the south side of the valley. It is seventy-nine feet in horizontal circumference, three feet from the ground; and a tape stretched across the exposed portion, from side to side, over the highest point, measured 46 feet. The Indians place on it offerings to Manitou, and at the time of our visit it contained beads, bits of tobacco, fragments of cloth and other trifles."

As the Aiktow Erratic is located in the upper part of the Qu'Appelle Valley which will become flooded upon completion of the South Saskatchewan River Dam and because the boulder is of historic interest, moving the erratic to the high bank of the valley is contemplated. Although this is a herculean task for humans, the energy to be expended in this move is only an insignificant fraction of the work performed by the glacier which moved this piece of rock over a distance of at least 320 miles from the Precambrian Shield and from an original altitude of about 1250 feet to its present resting place at 1750 feet.

\title{
A Garganey duck in the Wild in Alberta
}

by Lawson G. Sugden, Can. Wildlife Service, Edmonton

An adult drake Garganey (Anas querquedula) was seen at a lake near Two Hills, Alberta, on June 22, 23, and 24,1961 . On the last day I was accompanied by Ronald H. Mackey, Canadian Wildlife Service, Edmonton. We observed the duck from about 100 yards through a 25-power telescope. It was observed standing on land, swimming and flying. Attempts to collect the bird were unsuccessful. It was in company with a flock of Blue-winged Teal ( $A$. discors), predominantly males, which were very wild.

Delacour (The Waterfowl of the World, London, 1956, Vol. 2, p. 163) describes the male Garganey in breeding plumage as follows:

a black crown and throat, broad, long white supercilia joining on the nape, and the rest of the head and neck brownish chestnut streaked with white; mantle, black and tail blackish brown with pale borders to the feathers; wings generally as in other species of the group (blue-winged ducks), the long lanceolate, ornamental scapulars glossy black with a broad central white line, the wing coverts pale bluish grey, the mirror light between two wide white bands; breast light brown laced with black; rest of underparts white, finely waved with black on the sides and spotted on the vent and undertail coverts. Iris brown; bill and legs leaden grey."

The Garganey is similar in size to the Blue-winged Teal. The most dis- tinctive features of the Two Hills' duck were the long white supercilia on the head and neck, the black lanceolate scapulars with central white line, the pale-bluish wing coverts, and the whitish underparts.

Previous to this time neither $\mathrm{Mr}$. Mackay nor I had seen a Garganey. However, a month prior I had collected a strange-looking Blue-winged Teal drake which I thought might be some form of hybrid. It had the supercilia on the head and neck which joined the white crescent of the Blue-winged. This suggested a Garganey characteristic. Otherwise it resembled the Blue-winged. (According to $\mathrm{Mr}$. W. Earl Godfrey, National Museum of Canada, it is a partial albino Blue-winged.) Consequently, I was familiar with the description and illustration of the Garganey in Delacour's book. In addition, we both reviewed this information prior to the last day's observation. There is no doubt in our minds about the identification. All observable details of the duck's appearance matched those given in the book.

Breeding range of the Garganey covers much of Europe and Asia from the British Isles to north-eastern Siberia. The species is not men- 
tion in The A.O.U. Check-list of North American Birds (1957). Correspondence with zoos and avaries in western Canada indicate that it has not been kept in captivity here. However, it is apparently kept in some zoos in the western United States. The duck in question may have escaped captivity and migrated north, possibly mated to a Blue-winged Teal. I favour that explanation for its presence in Alberta, rather than the possibility that it represents an erratic wanderer from its indigenous range.

\title{
Banded Ross' Goose Recovered in Regina
}

\author{
by Douglas E. Wade and Dorothy R. Wade, Regina
}

On December 5, 1962, Mrs. Wade saw a white goose on the open water of the Regina Waterfowl Park. On December 6, in company with Margaret Belcher and Robert Nero, we were unable to get a close enough view of this goose to determine whether it was a Snow Goose or a Ross' Goose. On December 9, we were able to see it at close range through $12 \mathrm{X}$ binocoulars and saw there was no "grinning patch." On December 15, we were able again to get close to the bird and could see a metal band on its right leg and confirm the absence of a "grinning patch." The goose was seen subsequently by us on December 19 and 30 . On all of these dates the bird appeared to be in excellent flying condition and was often seen in flights with Canada Geese and Mallards. It would land and take off with no apparent difficulty. It was an active feeder and was seen going through preening activities. It was also seen by George and Marjorie Ledingham, Vic Wilshire, Allan Smith and Alan Wade-the last three on the Christmas Count day (December 30). Fred Lahrman, of the Saskatchewan Museum of Natural History, had been able to see the goose and had determined it to be a Ross' Goose.

On January 5 and 6 we and two other groups were unable to spot the zoose. Later, we learned that the 'Ross' Goose had been found dead on January 6 in one of the open-water channels across from the city power house by Ricky Sanderson. He turned the bird over to the Museum of Natural History to be prepared as a specimen. The Museum reported its weight as 2 lbs. 91/2 oz. Ralph Carson of the Museum also reported that the carcass showed evidence of several hotgun pellets having recently pene- trated the body. Presumably the bird had been shot at (illegally) when going to feed in grain stubble beyond the city limits. There was no evidence of lead shot in the gizzard, although some wheat grain remnants and quartz sand-size granules were found. The goose was a female.

Knowing that a number of Ross' geese had been banded in Saskatchewan, we got in touch with Mr. Alex Dzubin, wildlife biologist with the Canadian Wildlife Service in Saskatoon. In his letter of January 7 he wrote:

“The Ross' Goose No. 667-65331 which you observed in Regina and which was subsequently recovered has the following history. It was an adult female banded on September 30,1962 , at Buffalo Coulee, which is situated four miles north and four miles west of Colville, Saskatchewan, at $51^{\circ} 46^{\prime} \mathrm{N}$. and $109^{\circ} 18^{\prime} \mathrm{W}$. in the Kindersley District of west-central Saskatchewan. The bird was the last one banded of 141 Ross' caught by cannon net traps on that day. A crew made up of personnel of the Canadian Wildlife Service, Nebraska Game, Forestation and Parks Commission, U.S. Bureau of Sports Fisheries and Wildlife, and Colorado Game and Fish Department co-operated in the fall banding project at Kindersley.

"Total bandings of this species [in 1962 ] were 770 . Last year's total was 442. Most Ross' winter in the Sacramento Valley of California; the few recoveries of 1961 birds are from this wintering area. No recoveries l except the Regina bird] of 1962 banded birds are available as yet but I have a half dozen sight recoveries of red and yellow dyed Ross' from Montana and central California." 